\title{
Makna Sebagai Tanda
}

\author{
Muhammad Yunis \\ Fakultas Ilmu Budaya Universitas Andalas \\ E-mail: yunissasda@gmail.com
}

\begin{abstract}
Semiotic explains about meanings and signs. The meanings and signs itself are the two things that are growing and developing from the human's concept of the universe as a way in defining the life. Comprehending the meaning and sign by Pierce, Barthes, Umberto Eco, or even Piliang concepts will view that those meanings and signs can be interpretated as a life reality which are exist in every relationship of human and God and also human and the nature.
\end{abstract}

Keywords—semiotic, meaning and sign.

\section{Pendahuluan}

Di saat kita berbicara makna dan tanda, kita akan terbayang pada konsepnya Pierce, Barthes, Umberto Eko ataupun Piliang yang memunculkan konsep tanda dan makna itu sendiri. Makna berpotensi menjadi segala-galanya, makna berpotensi sebagai titik penentu dalam duania realitas. Dengan adanya makna sebagai tanda, hidup akan lebih bermakna ataupun sebaliknya, artinya dengan memperhatikan tanda kita akan mengetahui makna hidup itu sendiri dan makna sebagai pengendali keberlangsungan hidup manusia di alam jagad raya.

Bagaimana tidak, Tuhan dapat dianggap sebagai tanda dan Tuhan juga berpotensi sebagai makna bagi kehidupan manusia. Karena adanya Tuhan manusia takut bersalah, berdoasa dan karena Tuhan pula manusia mau berbuat dosa dan mengingkari fitrahnya sebagai manusia dan menggantikan posisi Tuhan sebagai makna itu sendiri. Untuk itu kita harus tahu dulu apa itu tanda dan makna

\section{TANDA}

Dalam melihat tanda Pierce berpijak pada konsep awalnya tentang tanda, dia menyebutnya dengan Semiotika. Semiotika adalah studi tentang tanda dan segala yang berkaitan dengannya, fungsinya, hubungannnya dengan tanda lain, pengirimnya dan penerimanya oleh mereka yang menggunakannya (Pierce dalam Zoest, 1992: 1-5). Tanda terbagi menjadi 2 bagian, penanda yaitu citra bunyi, sedangkan petanda yaitu gagasan atau konsep (Untung dan Cristomy, 2004:20). Sementara itu versi Tonil, semiotika adalah ilmu tentang tanda yang mempelajari fenomena budaya, termasuk sastra sebagai sistem tanda (berhala semiotika, 2000:1). Namun yang pastinya, Ferdinand De Saussure sebagai juga salah seorang semiotikus ini, meskupun tidak penah berpretasi menjadi Semiotisian, karena pusat minatnya ialah bahasa, tetapi dialah yang pertama kali mencetuskan gagasan untuk melihat bahasa sebagai sistem tanda. Namun begitu, tanda lebih populer di masanya Charles Sanders Pierce, dia melihat tanda dari tiga hubungan (Relation) yaitu hubungan tanda dengan sifat Ground, hubungan tanda dengan Denotatum dan hubungan tanda dengan Interpretant.

Sepertinya Pierce adalah seorang manusia yang ganjil, serba tiga, begitu pula kategorei tanda yang dia kemukan serba tiga. Hubungan tanda dengan sifat terdapat tiga kelompok; Qualisigns adalah 
tanda-tanda yang merupakan tanda beradasarkan suatu sifat. Contohnya, sifat merah merupakan Qualisign, karena merupakan tanda pada bidang yang mungkin. Agar merah benar-benar berfungsi sebagai suatu tanda, maka merah harus diberi bentuk. Maka, merah digunakan sebagai tanda. Contohnya, bagi sosialis pada bendera merah dan untuk menyatakan cinta dengan memberi mawar merah ke pada seseorang. Jadi, merah sudah diberi bentuk seperti pada bendera sosialis dan pada mawar. Berarti Qualisigns yang murni menurut Pierce tidak ada dan Qualisigns sebagai tanda dasar harus tertanam pada bentuk yang lain supaya berfungsi sebagai tanda, ini hanya berlaku pada Qualisigns saja.

Sinsign adalah tanda yang merupakan tanda atas dasar tampilannya pada kenyataan. Semua pernyataan individual yang tidak dilembagakan dan tanda yang yang kita kenal tidak didasari oleh suatu kode disebut Sinsign. Contohnya, sebuah jeritan berarti tanda kesakitan, keheranan atau kegembiraan. Kita juga dapat mengenal orang dari cara batuknya, dehemnya, langkah kakinya, tertawanya, nada dasar dan suaranya.

Legisign adalah tanda atas dasar suatu peraturan yang berlaku umum, sebuah konvensi, sebuah kode. Contohnya, tanda-tanda lalu-lintas, mengangguk berarti tanda 'ya', mengarutkan alis, berjabat tangan dan lain-lain (Zoest, 1993:18-22).

Hubungan tanda dengan Denotatum, juga ada tiga kelompok; hubungan yang didasari oleh kemiripan disebut Ikon (Zoest, 1993:22-27). Contohnya, foto seseorang merupakan Ikon dari orang tersebut; hubungan yang didasari oleh adanya hubungan sebab akibat disebut dengan indeks. Contohnya, adanya asap berarti telah terjadi sebuah kebakaran, karena asap akan didahului oleh api; hubungan yang terbentuk beradasarkan kesepakatan, konvensi dan aturan yang berlaku umum disebut dengan Simbol. Contohnya, asap bagi orang Indian berarti simbol perang dengan Belanda, bukan menandai adanya kebakaran.

Hubungan tanda dengan Interpretant, juga terdapat tiga kelompok; Rheme adalah tanda yang dapat diintrepretasikan dengan dua kemungkinan Denotatum. Contohnya, perkataan ''kursi ", merupakan sebuah bahasa, tapi tanpa konteks, kata ini hanya mempunyai kemungkinan denotata. Apabila kata kursi diberi konteks, maka kursi dapat menciptakan kemungkinan-kemungkinan
Interpretant (Dalam Zoest, 1993: 27-30). Bisa saja acuannya kursi pejabat, DPR, MPR dan sebagainya. Desicign adalah tanda apabila tanda menawarkan hubungan yang benar-benar ada di antara tanda Denotatum. Ini, termasuk tanda yang informatif. Hal ini, dapat dibuktikan kebenarannya. Contohnya, Presiden SBY datang ke UI, ini dapat dibuktikan kebenenarannya, apakah benar Presiden datang ke UI pada waktu tersebut? Artinya, tanda ini didukung oleh faktor eksternal. Argument adalah suatu proses berfikir yang membuat orang memproduksi kepercayaan terhadap sesuatu, untuk itu diperlukan proses lain untuk mendukung Argument ini. Artinya, kebenarannya didukung oleh faktor internalnya sendiri. Contohnya, semua mahluk pasti mati, Malaikat ialah mahluk, Malaikat pasti mati.

Kemudian terdapat ahli semiotik lain yaitu Barthes. Pendekatan dalam semiotik Barthes, melihat teks sebagai tanda yang memiliki segi ekspresi dan isi. Oleh karena itu teks ia lihat sebagai: (1) suatu maujud yang mengandung unsur-unsur kebahasaan, (2) suatu maujud yang untuk memahaminya harus tertumpu pada kaidahkaidah yang terdapat dalam bahasa teks itu, (3) sebagai suatu bagian dari kebudayaan. Sebenarnya semiotik ala Barthes dengan Pierce mempunyai kesamaan konsep, hanya saja pada teori Barthes lebih bersifat tertutup sedangkan pada teori Pierce lebih terbuka, karena proses semiosis menurutnya tidak terbatas.

\section{MAKNA}

All paragraphs must be indented. All paragraphs must be justified, i.e. both left-justified and right-justified.

Untuk mengetahui apa itu makna kita akan menoleh pada duani realita tempat makan itu direalisasukan, kita mengenal gulat atau pertandingan gulat? Di sana terjadi perkelahian antara dua orang yang berbeda dan ditengahi oleh wasit. Dari kenyataannya gulat adalah tontonan ditempat terbuka, yang mana para khalayak cekikikan saat melihat adegan yang disenangi. Sejalan dengan itu gulat menggambarkan penderitaan, kesedihan dan keadilan. Sehingga muncullah pandangan bahwa gulat adalah susatu olah raga yang hina, sarat dengan kekerasan fisik, terkadang itu pula penonton sering terpancing emosinya karena pegulat andalannya menderita kekalahan. Dalam mitosnya Roland Barthes gulat 
dianggap perkelahian antara yang baik dengan yang buruk (Barthes, 2003: 15). Namun kedua pegulat kenyataannya di dalam gulat itu sendiri menggambarkan ketiadaan etika, kesopanan dan ketidak disiplinan. Hal ini jelas terlihat saat lawan main ingin bersalaman, tapi ternyata lawan langsung bereaksi dengan mempelintir tangan, dan wasit yang ingin melerai juga jadi sasaran. Anehnya adegan kekerasan tersebut mampu membuat senang dan para penonton berteriakteriak kegirangan.

Nah, di dalam gulat tersebut sebenarnya telah terjadi permainan tanda yang hiperbola, apa yang disebut Piliang (2003) dengan tanda artifisial, yang mana di sini tanda diolah dan dibesarbesarkan sedemikian rupa hingga menampilkan suasana yang wah dan di saat penonton menyaksikan itu penonton merasa senang dan bahagia.

Jika kita lihat apakah sesungguhnya makna gulat? Perhatiakanlah di saat pertandingan gulat usai para penonton dengan santai, melengok ataupun berbimbingan tangan dengan kekasih atau istri menuju keluar dan pulang ketempat masingmasing. Di sini dapat kita lihat bahwa kekerasan dan ketidak berdayaan sekaligus keadilan yang tergambar dalam gulat tidak menjadi pengaruh apa-apa bagi penonton selain kesenangan sesaat atas penderitan orang lain atau hanya hiburan sementara. Dapat disimpulkan bahwa gulat hanya bersifat hiburan bagi masayarakat moderen yang mungkin melepaskan penat dan letih di saat bekerja, tapi dibalik itu makna yang muncul dengan hadirnya olah raga gulat adalah ketiadaan dan penepian spiritual, menepikan gereja.

Sejalan dengan itu kita lirik pula pertunjukan randai di Indonesia, di sana juga menampilkan kesedihan, penderitaan, peperangan dan segala macam konflik sehingga secara tidak sadar penonton pun terbawa arus kesedihan, seakanakan persitiwa itu nyata adanya. Betul dalam pertunjukan randai sering mengangkatkan peristiwa-peristiwa yang pernah terjadi di alam lingkungan Minangkabau, tetapi tidak terjadi di saat itu. Di randai itu pula terdapat pesan-pesan bagi penonton tentang akibat dari perbutan baik dan buruk. Sebagian orang dapat menjadikan pertunjukan randai sebagai sarana didikan, penyampai pesan pada pemuda, pemudi maupun masyarakat. Nah, di sini juga dapat kita lihat bahwa pertunjukan randai sebenaranya hanyalah hiburan saja, lihat saja seketika randai usai baik penonton maupun pemain pulang dengan tanpa beban, tanpa rasa bersalah.

Di sini, pertunjukan randai bermakna sebagai pelestarian budaya daerah, dan nilai-nilai seni tradisi yang pernah dimiliki oleh orang Minangkabau. Namun seyogyanya di sana terdapat kerinduan masyarakat akan kenangan dan kejayaan Minangkabau masa lalu, tentang harta pusaka, mamak, dan kemenakan, dan ternyata randai juga mampu menepikan sholat lima waktu seperti yang terjadi di dalam gulat di atas.

Kita perhatikan pula dunia sekarang, yang mana mesin-mesin menguasai manusia sebagai penciptanya, ketika ruang dikalahkan oleh waktu, ketika tindakan telah dipadatkan, dan di saat makna kehilangan perannya di dalam realitas, maka saat itulah terciptanya Tuhan-tuhan baru. Di awali dengan perlombaan mengejar nafsu; nafsu ekonomi, nafsu politik, nafsu materi, benda-benda, hingga nafsu sexs. Alhasil, sebagian nilai-nilai mulai kehilangan makna di dalam realitas, karena realitas kini diciptakan telah melampoi batas-batas alamiahnya sebagai realitas, para ahli menyebutnya dengan hyperealitas.

Begitulah di saat manusia dikuasai oleh nafsu, semua serba simpel dan instans. Tampaknya, siapa saja yang mampu memepermainkan tanda, dengan mengangggap penanda (subjek) sebagai penguasa yang mengeksploitasi petanda (objek) dialah yang akan maju, sementara bagi siapa yang cenderung diam akan tergilas dalam percaturan global. Semua informasi berskala dunia dapat diakses lewat media internet. Berita skandal sexs madona, skandal artis ngetop, free sexs, cybersexs, violence dapat diakses dengan sekejap, seakan-akan dunia ini tanpa pembatas. Namun, semuanya itu adalah kenisbian, tanpa tujuan, tanpa akhir yang nyata, semua berada pada titik kesemuan belaka. Sementara manusia itu sendiri sebagai pencipta mesin telah dikuasai oleh ciptaannya, punya ilmu pengetahuan yang tinggi tetapi diperbudak oleh ilmunya, ahli filsafat nyatanya menjadi budak filsafat, ahli kebudayaan tetapi dipenjara oleh kebudayaan itu sendiri.

Sehingga akhirnya manusia kembali pada masa primitif yang tanpa kebudayaan. Padahal kebudayaan yang telah diwariskan oleh leluhur sangatlah agung dan serat dengan nilai-nilai moral, hal ini berguna sebagai tuntunan dalam hidup. Masyarakat dulu contohnya, mengenal 
kekeluargaan, kegotong-royongan demi kemajuan bersama.

Akibat dari itu muncul keinginan untuk kembali menciptakan sistem nilai, norma-norma namun di dalamnya mungkin sudah ditunggangi oleh kepentingan akan materi dan kekuasaan saja. Kalau tidak menguntungkan, nilai dan normanorma itu tidak akan bertahan lama. Tanah pusaka yang dijual penghulu, gelar adat diperjual belikan, arsip-arsip lama yang digadaikan ke luar negri, hingga spiritual jadi barang dagangan.

Siapa yang tidak tahu ESQ power? Ini adalah bentuk nyata dari virus Cyber ciptaan manusia, kian hari kian merusak jaringan-jaringan spiritual itu sendiri. Mungkin virus ini yang mengambil alih dakwah dan berkata, 'wahai manusia bertobatlah, dekatkan diri kepada penciptamu, tapi dengan bayaran tentunya!’. Begitu berharganya spiritualitas.

Sekarang, sudah jarang terdegar para penyair yang berkata pada ilalang, bercengkrama dengan rumput yang bergoyang, bercerloteh dengan burung camar, sebab penyair sudah kehilangan makna ilalang, kehilangan makna rumput yang bergoyang, dan juga kehilangan merdunya siulan burung camar. Tiada lagi kesunyian, menyepi dalam mencari inspirasi. Kalau dulu kesunyian dapat menimbulkan imajinasi, dapat bertemu Tuhan dan berdialog dengan Tuhan melalui zikir sehingga tubuh ini mengawang.

Namun sekarang tiada lagi ruang sunyi, ruang penyepi untuk beristitarahat sejenak dari kepenatan dunia, sebab dimanapun kita berada, dunia sunyi mana yang dipilih tetap saja dikejar oleh kecanggihan teknologi. Menyendiri di dalam rungan tidak bisa karena ruang telah ditaklukan oleh waktu, setiap sudut ruangan telah diakses internet, menyendiri dalam gua tetap tidak bisa karena telah ditaklukan oleh Handphone, mau mematikan handphone tetapi takut ketinggalan informasi sebab resikonya adalah digilas dan ditinggalakan oleh globalisasi.

Andai saja hiburan hanya sebatas pelepas dari lelah bekerja realitas akan sedikit lain. Tetapi kebudayaan Hyper melewati batas tersebut, membaca sambil memegang remot control, berbicara sambil di WC, mengetik sambil dengar musik, semuanya serba cepat hingga tiada tersisi satu nafaspun untuk istirahat, sekali lagi sebab konsekwensinya adalah digilas oleh globalisasi.
Akibat dari itu Virus mengambil alih propesi pendakwah dan menyadarkan manusia dari kehilangan tujuan. Virus spiritual seperti yang telah dijelaskan di atas. Kemudian virus HIV/AIDS sebagai pendakwah pecandu free sexs, virus UU pornografi dan porno aksi bagi orang yang suka mempertontonkan keindahan tubuh di tempat umum. Namun begitu, setelah timbulnya virus pendakwah tersebut tetap saja manusia Hyper tidak sadar, muncul UU pornografi dan porno akasi tetapi lokalisasi dilegalkan, muncul Virus HIV/AIDS tetapi kondom selalu diproduksi sebagai alat pengaman, muncul juga Virus ESQ tetapi setelah membaur kembali kedalam dunia realitas pribadi-pribadi kembali kedalam dunia mimpi.

Memang sudah digagas oleh Yasraf Amir (2004:120) bahwa untuk mengembalikan manusia kontemporer pada dunia kedalaman spiritual, kehalusan hati, dan ketajaman hati ditengahtengah bujuk rayu, dan kepalsuan masyarakat konsumer, maka sebuah ruang bagi pengasahan spiritual harus dibangun kembali dari puing-puing reruntuhannya. Yasraf mencemaskan jika itu tidak dilakukan maka masyarakat global akan hanyut dalam belantara bujuk rayu, keterpesonaan, dan ketergiuran tanpa akhir dan tenggelamlah ke dalam lembah ekstasi yang ekstrim.

\section{IV.KESIMPULAN}

Nah, jika kita renungkan lebih mendalam sesungguhnya telah terjadi pemutusan hubungan dengan Tuhan, berganti Tuhan kepada dunia citraan, elektronik, dan segala macamnya. Tidak salah Nizche menyebut kematian Tuhan, kematian spiritualitas, karma tidak berlaku, hukum alam mampu ditaklukan oleh manusia dengan hukum buatan sendiri. Di sini sudah jelas munculnya tanda-tanda kejahiliyahan, Animisme, Dinamisme dan tanpa sadar dinikmati oleh masyarakat sekarang tanpa sadar. Maka dari itu tidak tertutup kemungkinan manusia menjadi Tuhan bagi manusia lain.

\section{REFERENCES}

[1] Barthes, Roland. 2003. Mitologi. Padang: Dian Aksara Press

[2] Nietzcshe, Friedrich. 2004. Terjemahan; Ece Homo, Lihatlah Dia. Yogyakarta: Pustaka Pelajar.

[3] Nietzcshe, Friedrich. 2001. Terjemahan; Zarathustra. Yogyakarta: Jejak

[4] Piling, Yasraf Amir. 2006. Dunia Yang Dilipat, Tamasya melanpou Batas-batas Kebudayaan. Yokyakarta dan Bandung: Jala Sutra. 
[5] ------------------. 2003. Hiper Semiotika, Tafsir Cultural Studies Atas Matinya Makna. Bandung: Jala Sutra.

[6] Padang Ekspres, 25 Oktober 2008; hal.13, 'Di saat Cyber Membudi Daya'.
[7] Tonil. 2000. Berhala Semiotika. Yokyakarta: Tonil Press.

[8] Yuwono, Untung dan T. Cristomy. 2004. Semiotika Budaya. Depok:

Direktorat Riset dan Pengabdian Masyarakat Universitas Indonesia.

[9] Zoest, Art Van. 1993. Semiotika. Jakarta :Yayasan Sumber Agung 